\title{
Market-Sensing Capability and Business Performance of Retail Entrepreneurs
}

\author{
Arto Tapio Lindblom \\ Helsinki School of Economics \\ E-Mail: arto.lindblom@hse.fi \\ Rami Mikael Olkkonen \\ Turku School of Economcis \\ E-Mail: rami.olkkonen@tse.fi \\ Lasse Mitronen \\ Kesko Ltd. \\ E-Mail: lasse.mitronen@kesko.fi \\ Sami Kajalo \\ Helsinki School of Economics \\ E-Mail: sami.kajalo@hse.fi
}

\begin{abstract}
This study aims to shed light on the market-sensing capabilities of retail entrepreneurs and the effect of these capabilities on their business performance. A conceptual model based on a literature review is presented, followed by an Internet survey of 226 K-retailers from the Finnish K-alliance. Structural equation modeling (SEM) is used to test the conceptual model and to investigate the effect of market-sensing capability on growth and profitability. The study reveals that most of the studied retail entrepreneurs have relatively well-developed market-sensing capabilities. A weak positive relationship is found to exist between market-sensing capability and company growth. However, no positive relationship is found between market-sensing capability and profitability. Factors other than market-sensing capability were not considered in the present study. However, other factors that might affect business performance in the
\end{abstract}


present research context are identified and discussed. The article sensitizes practitioners to think how entrepreneurs' market-sensing capabilities should be conceptualized and developed in the retail chain context. The paper presents a novel and distinctive empirical investigation of the relationship between entrepreneurs' market-sensing capability and firm performance in the retailing context.

Keywords: Market-Sensing, Capability, Profitability, Growth, Retail Entrepreneurs

\section{INTRODUCTION AND PURPOSE}

It has been argued that firms must develop capabilities in key functional areas if they are to gain and hold positions of competitive advantage (Prahalad \& Hamel, 1990; Vorhies, 1998). These capabilities should be difficult to imitate and should support the organization's business strategy (Day \& Wensley, 1988; Barney, 1991; Day, 1994). The development of key marketing capabilities has been identified as one of the main ways by which firms can achieve innovations and competitive advantage (Day \& Wensley, 1988; Day, 1994; Vorhies, 1998; Weerawardena, 2003; Weerawardena \& O’Cass 2004).

According to Vorhies (1998), a marketing capability is developed when a firm's marketing employees repeatedly apply their knowledge and skills to the transformation of marketing inputs to outputs. To effect this transformation, these intangible resources (of knowledge and skills) usually are combined with tangible resources or assets. Marketing capabilities thus can be understood as integrative processes whereby the collective knowledge, skills, and resources of a firm are applied to the market-related needs of the business - thus enabling the business to add value to its goods and services, adapt to market conditions, take advantage of market opportunities, and overcome competitive threats (Day, 1994).

Every business acquires many capabilities that enable it to carry out the activities required to move its products or services through the value chain (Day 1994). Some capabilities will be adequate, and others will be poor, but a few must be superior if the business is to outperform the competition. Weerawardena (2003) has described such distinctive (superior) capabilities as providing an organization with the capacity to deliver products and services to the market in a manner that outperforms competitors. Day (1994) has emphasized that these distinctive capabilities must be managed with special 
care through a focused commitment of resources, the assignment of dedicated people, a commitment to ongoing efforts to learn, and the pursuit of dramatic goals for improvement. According to him, a distinctive capability is a key success factor that makes a disproportionate contribution to the provision of superior customer value and enables the business to deliver value to customers in an appreciably more cost-effective way.

Day $(1994 ; 2002)$ has studied extensively the role of capabilities in creating a market-oriented organization (see, e.g., McKitterick, 1957; Kohli \& Jaworski, 1990; Jaworski \& Kohli, 1993; Slater \& Narver, 2000a; Noble et al., 2002; Vorhies \& Harker, 2000). According to Day (1994) market-oriented organizations seem to have superior market-sensing, customer-linking, and channel-bonding capabilities. The classical study by Kohli and Jaworski (1990, p. 9) defined market orientation as essentially an informational construct, calling it "the organization-wide generation of market intelligence pertaining to current and future customer needs, dissemination of the intelligence across departments, and organization-wide responsiveness to it." Narver and Slater (1990) offer another definition in the same spirit. They distinguish three behavioral components: customer orientation - the firm's understanding of the target market; competitor orientation - the firm's understanding of the long-run capabilities of present and prospective competitors; and interfunctional coordination-the coordinated utilization of company resources to create superior customer value. The market orientation concept is related closely to the concept of learning orientation, which can be defined as the process of improving actions through better knowledge and understanding (Foley \& Fahey, 2004; see also Baker \& Sinkula, 1999). Theoretically speaking, the market orientation and learning orientation literatures are very close, and there has been a struggle in the literature with regard to the causality of learning orientation and market orientation (Foley \& Fahey, 2004; Farrell \& Oczkowski, 2002; Santos-Vijande et al., 2005). For Day (1994), a market-sensing facility precedes market orientation; for Slater and Narver (1995), market orientation is the principal cultural foundation of the learning organization.

Without entering into quite complex conceptual debate between learning orientation and market orientation, this study will concentrate conceptually on market-sensing capability, realizing that it is an essential element of market-oriented behavior and that, inherently, it includes organizational learning regarding, e.g., customers' explicit and latent needs. Actually, according to Day (1994), the Kohli and Jaworski (1990) definition 
of market orientation presented above captures the essence of a market-sensing capability quite well. Each element of their definition describes a distinct activity having to do with collecting and acting on information about customer needs and the influence of technology, competition, and other environmental forces. The concept of market-sensing capability refers to a firm's ability to learn about its market environment, and to use this knowledge appropriately to guide its actions (Day, 1994; see also Vorhies \& Morgan, 2005).

For some time, marketing researchers have been investigating the nature of the relationship between market orientation and entrepreneurship, and the implications of this relationship for business performance (Bhuiana et al., 2005; Santos-Vijande et al., 2005). For example, Slater and Narver (1995) argued that a market-oriented culture can achieve maximum effectiveness only if it is complemented by a spirit of entrepreneurship. Hult and Ketchen (2001) suggested that market orientation and entrepreneurship are organizational capabilities that contribute to the creation of a unique positional advantage, which affects business performance positively. Atuahene-Gima and Ko (2001) argued that the maximum positive effect on business performance is achieved when a firm's market orientation and entrepreneurship are aligned. Weerawardena (2003) suggested that entrepreneurship, marketing capabilities, and competitive-advantage process are strongly related. He also said that entrepreneurial decision-making is the key factor that drives the competitive-advantage process because entrepreneurs have the distinctive capabilities needed to exploit superior value-creating market opportunities.

Despite the growth of studies related to market orientation and entrepreneurship, studies on entrepreneurs' market-sensing capabilities and the effect that such marketsensing capabilities have on their business performance have remained relatively sparse (see, e.g., Lindblom, 2006). To fulfil this research gap, at least to some extent, the purpose of this study is to analyze the market-sensing capabilities of retail entrepreneurs and assess the effect of such market-sensing capabilities on their business performance. To be more specific, the objectives of the present study are to investigate:

1. the degree of market-sensing capability among the studied retail entrepreneurs

2. the nature of the relationship between business performance (growth and profitability) and market-sensing capability of the retail entrepreneurs.

The subjects of the study are K-retailers in Finland. K-retailers are independent entrepreneurs who are owners and managers of their retail businesses, and who invest 
considerable personal and financial resources in these enterprises. K-retailers belong to $\mathrm{K}$-alliance, one of largest retail organization in Finland, which includes Kesko, Finnish K-retailers, and the K-retailers' Association (Mitronen \& Möller, 2003).

\section{THEORETICAL BACKGROUND}

Generally, organizational capabilities (Prahalad \& Hamel, 1990; on dynamic capabilities, see, e.g., Teece et al., 1997) can be connected to a resource-based view of the firm (RBV), which is originated in the strategy literature (Rumelt, 1984; Wernerfelt, 1984; see also Srivastava et al., 2001). The resource-based view of the firm rests on a simple premise that the organizations' desired outcome is to achieve a sustainable competitive advantage that allows them to earn economic rent or above-average returns (see Fahy \& Smithee, 1999). The key to earning this reward is the possession of critical resources that are firm-specific, valuable to customers, non-substitutable, and difficult to imitate, and that lead (if deployed effectively) to a sustainable competitive advantage (Barney, 1991; Foley \& Fahy, 2004; Fahy \& Smithee, 1999). This perspective emphasises firm-specific capabilities and assets and the existence of isolating mechanisms as the fundamental determinants of firm performance.

Capabilities generally can be defined as complex bundles of skills and collective learning, exercised through organisational processes that ensure superior coordination of functional activities (Day, 1994). One capability is stated to be critical in developing successful businesses: the market-sensing capability, which is essentially the ability of the organization to be aware of change in its market and to forecast accurately responses to its marketing actions (Day, 1994). According to current literature, market-sensing capabilities refer to a firm's ability to use market intelligence that can be obtained through formal (e.g., reports) and informal (e.g., hall talk) mechanisms from various personal and public sources (Maltz \& Kohli, 1996; Menon \& Varadarajan, 1992; Moorman et al., 1992). Generally, market-sensing capabilities are critical in developing market focus and thus, ultimately, company performance (Day, 1994).

Many authors state that learning is an essential part of market-sensing capability. As mentioned earlier, Day (1994) has stressed the need to conceptualize market-sensing as an organizational learning capability to advance strategic marketing by learning about customers, competitors, and channel members with a view to acting on events and trends in markets. Huber (1991) has described such market-sensing as the capacity of a firm to 
acquire and disseminate knowledge, and to use market information for organizational change as required.

In accordance with Day $(1994 ; 2002)$, market sensing can be divided into three subprocesses: (i) sensing, (ii) sense-making, and (iii) response. In short, sensing refers to acquisition of information on consumers, competitors and other channel members, whereas sense-making refers to the interpretation of gathered information against past experiences and knowledge. Response refers to utilization of the gathered and interpreted information in decision-making. In other words, through response, the intangible information and knowledge is turned into visible marketing action. Day (2002) underlines that the processes for market-sensing are more systematic, thoughtful, and anticipatory in market-oriented firms than they are in other firms, in which these processes tend to be ad hoc, reactive, constrained, and diffuse.

The elements of market sensing capability and their interrelatedness, as well as their link to the firm performance, are presented in Figure 1. Following Day (2002), it can be assumed that organizations that have mastered the market-sensing activities gain competitive advantage and superior business performance. In other words, an organization's ability to learn about its market environment and use this information appropriately to guide its actions is the key driver of business performance (Vorhies \& Morgan, 2005). In the focal study, the business performance of retail entrepreneurs is divided into (i) profitability and (ii) growth.

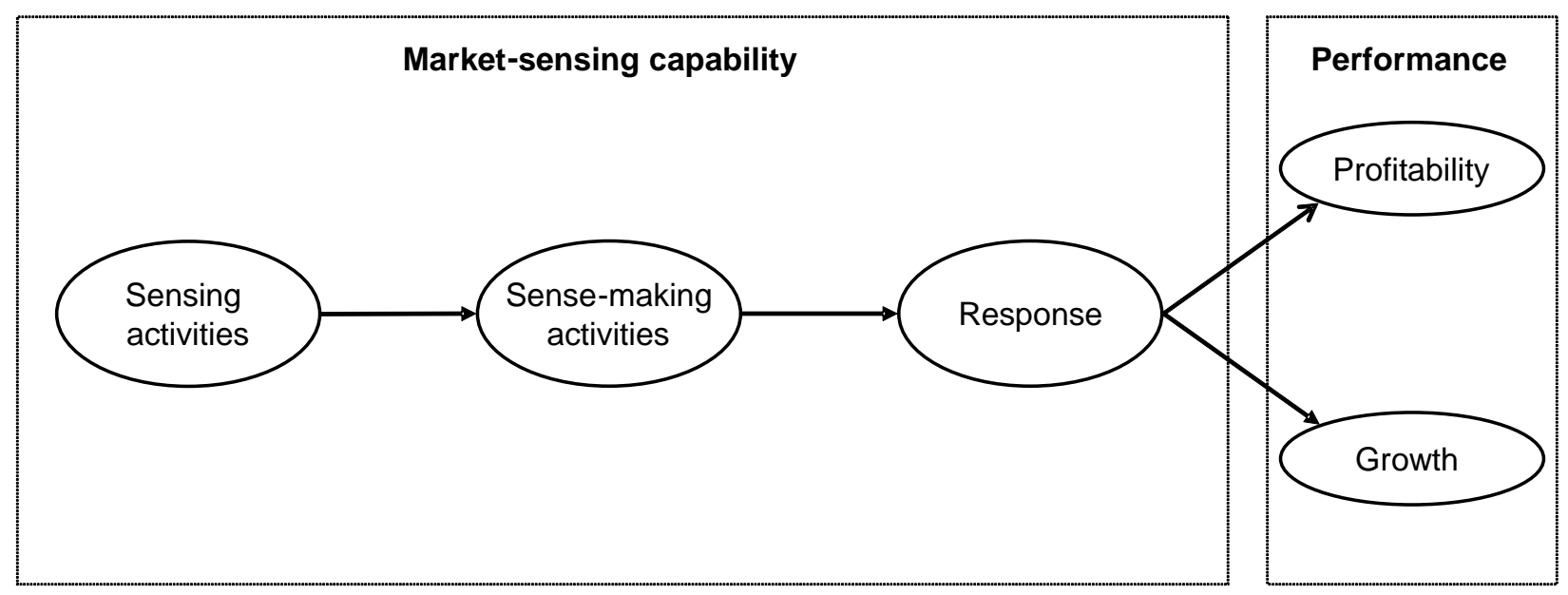

Figure 1 Conceptual model of the study (see Day, 2002) 
According to Day (2002), mastery of the complete market-sensing process is rather demanding and rare. Most firms suffer disabilities at one or more stages of the process. Their inquiries may be constipated, their mental models myopic, the circulation of information constricted, or the collective memory afflicted by amnesia. The cost of these disabilities is high and mounting rapidly in markets experiencing accelerating rates of change. Yet, organizations can learn to sense their markets better by understanding each step in their process, critically assessing their market learning capability, and then correcting the learning disabilities. Therefore, mastering each stage in the market-sensing capability model is of utmost importance.

In the empirical part of the study, the degree of market-sensing capability among the studied retail entrepreneurs, and the nature of the relationship between business performance and market-sensing capability of the retail entrepreneurs, is investigated more profoundly.

\section{RESEARCH DESIGN}

The basic research design of this study was an informed survey of a sample of Kretailers. K-retailers offer a varied selection of retail services to consumers-including groceries, building supplies, interior-decoration items, household goods, and speciality goods. These services are offered to consumers though a variety of store formatsincluding small convenience groceries, specialty stores, department stores, and large hypermarkets (Mitronen, 2002; Mitronen \& Möller, 2003).

$\mathrm{K}$-alliance is a retailer-sponsored voluntary chain that differs fundamentally from other large international retail organizations, such as Wal-Mart and Tesco. The latter own all of their retail outlets and manage them centrally; they do not have independent entrepreneurs making independent decisions at the store level. In contrast, K-alliance is a strategic network that consists of Kesko and its subsidiaries and personnel operating in Finland and abroad, together with legally independent K-retailers and their personnel. In Europe, ICA AB in Sweden and Edeka in Germany have similar structures to that of Kalliance in Finland.

The sample for the present study consisted of 1,170 K-retailers from K-alliance. An Internet survey was conducted (with Webropol software) in May 2005. Having obtained the e-mail addresses of all K-retailers in Finland through the good offices of the Kretailers' Association, an initial e-mail was sent to each retailer describing the purpose of the study and requesting the retailer's participation. Approximately one week after the 
initial mailing, a second e-mail directed the retailers to a web site on which a survey questionnaire was located. Of the 247 K-retailers that completed the survey, 226 responses were satisfactory for data analysis. The overall response rate to the mailing was 19.3 percent. This can be considered satisfactory for the present analytical purposes. Respondents included both fast-moving consumer-goods retailers (63 percent) and consumer-durable goods retailers (37 percent).

The content of the questionnaire was determined on the basis of: (i) previous theoretical and empirical research into market-sensing capabilities; and (ii) several lengthy discussions with K-retailers and managers from Kesko. A pretest then was carried out by asking several K-retailers to complete the questionnaire. The objectives of the pretest were to assess whether retailers understood the questions and to determine how long it took to complete the questionnaire. No unclear items were found. This procedure, in its entirety, aimed to ensure the content validity of the study.

The market-sensing capabilities of K-retailers were conceptualized on the basis of Day's (1994; 2002) work. The term “market-sensing capability" thus was taken to refer to the ability of K-retail entrepreneurs to learn about their market environment (that is, their customers, competitors, and other channel members). Following the conceptual model of Day (2002), the construct of market-sensing capability was divided into three sub-constructs: (i) sensing; (ii) sense-making; and (iii) response. These sub-constructs were measured on multi-item scales. All items were measured on five-point Likert-type scales $(1=$ strongly disagree; $5=$ strongly agree). For each of the constructs, scale scores were computed as the sum of the individual items. If necessary, reverse scoring was done.

The following items were used to measure the sub-construct of "sensing":

- "I actively sense events and trends in my market environment"

- "My style of information-gathering is systematic"

- "I gather information regularly from different kinds of sources"

- "I actively exchange information with other K-retailers"

The following items were used to measure the sub-construct of "sense-making":

- "My style of interpreting the information is analytic"

- "I use a considerable amount of time to analyze the gathered information"

- "I actively analyze information before marketing decision-making" 
- "Analyzing information is useless when it comes to marketing decisionmaking"

The following items were used to measure the sub-construct of "response":

- 'I actively utilize information regarding consumers' needs and intentions when making my marketing decisions:

- "I actively utilize information provided by sales and market share reports regarding my retail outlet when making my marketing decisions"

- "I actively utilize data provided by sales and market share reports regarding the retail chain that I represent when making my marketing decisions"

- "I actively utilize data provided by profitability analyses regarding the retail chain that I represent when making my marketing decisions"

- "I actively utilize information provided by company image studies when making my marketing decisions"

Cronbach's alpha was used to test whether the items were sufficiently related to justify their combination as a sub-construct. Cronbach's alpha was 0.62 for the items in the sensing sub-construct, 0.63 for the items in the sense-making sub-construct, and 0.77 for the items in the response sub-construct. These alpha values indicate that the items were sufficiently related to justify their combination as sub-constructs (Nunnally, 1978; Nunnally \& Bernstein, 1994).

Overall market-sensing capability was measured by creating a composite variable from the sum of the values of the original variables used to operationalize the subconstructs of sensing, sense-making, and reflection. This composite variable had a satisfactory Cronbach's alpha of 0.78 . The overall construct and the three sub-constructs then were divided into value categories - according to: (i) the degree of market-sensing capability as a whole; (ii) the degree of sensing activities; (iii) the degree of sense-making activities; and (iv) the degree of response. Five value categories thus were established: 1 = very low; 2 = low; 3 = moderate; $4=$ high; and $5=$ very high.

The "business performance" of the K-retailers was posited as the ultimate dependent variable in the structural equation modeling. The present study therefore assessed "business performance" in terms of: (i) profitability; and (ii) growth (see, e.g., Morgan and Strong, 2003). Profitability was measured in terms of gross margin (percent) and operating margin (percent), which the respondents were requested to supply in the survey. (In passing, it is of interest that these two measures are used in K-alliance to 
assess business performance among K-retailers.) Growth was assessed through two survey questions: (i) past turnover growth compared to competitors; and (ii) expected turnover growth compared to competitors. Both questions were answered on a 5-point Likert-type scale.

\section{FINDINGS}

The first objective of the study was to assess the market-sensing capabilities of the K-retail entrepreneurs. The results for the sub-constructs (sensing, sense-making, and response) and for the overall construct of market-sensing capability are presented in Table 1.

Table 1 Market-sensing capabilities among K-retailers

\begin{tabular}{|c|c|c|c|c|}
\hline & $\begin{array}{l}\text { Sensing } \\
\text { activities }^{\mathrm{a}} \\
(\mathrm{n}=221)\end{array}$ & $\begin{array}{l}\text { Sense-making } \\
\text { activities }^{\mathrm{b}} \\
(\mathrm{n}=221)\end{array}$ & $\begin{array}{l}\text { Response }^{c} \\
(n=230)\end{array}$ & $\begin{array}{l}\text { Market sensing } \\
\text { capability }^{\mathrm{d}} \\
(\mathrm{n}=217)\end{array}$ \\
\hline Low & $12.2 \%$ & $7.7 \%$ & $2.2 \%$ & $7.8 \%$ \\
\hline Moderate & $66.5 \%$ & $59.0 \%$ & $18.6 \%$ & $52.5 \%$ \\
\hline High & $21.3 \%$ & $33.3 \%$ & $79.2 \%$ & $39.7 \%$ \\
\hline Total & $100.0 \%$ & $100.0 \%$ & $100.0 \%$ & $100.0 \%$ \\
\hline $\begin{array}{ll}\text { a } & \text { Cronbach } \\
\text { b } & \text { Cronbach } \\
\text { c } & \text { Cronbach } \\
\text { d } & \text { Cronbach }\end{array}$ & $\begin{array}{l}\text { e construct } \\
\text { e construct } \\
\text { e construct } \\
\text { e construct. }\end{array}$ & & & \\
\hline
\end{tabular}

The K-retailers had relatively high levels of market-sensing capability overall; the majority appeared to sense and act on events and trends in the market. With respect to the sub-constructs of market-sensing capability, the degree of response was relatively high among the respondents.

The second objective of the study was to investigate the effects of market-sensing capability on business performance. This analysis was conducted using structural equation modeling (SEM) via LISREL 8.72 (Jöreskog \& Sörbom, 2001). Modeling was undertaken deploying covariance matrix and maximum-likelihood estimation. Table 2 shows the fit indices for both the measurement model and the structural model. 
Table 2 Fit indices for measurement model and structural model

\begin{tabular}{l|lllll}
\hline Model & $\chi^{2}(\mathrm{df})$ & RMSEA & GFI & NNFI & CFI \\
\hline $\begin{array}{l}\text { Measurement } \\
\text { model }\end{array}$ & $\begin{array}{l}131.79(109) \\
\text { Significance }=.07\end{array}$ & .029 & .94 & .98 & .98 \\
\hline $\begin{array}{l}\text { Structural } \\
\text { model }\end{array}$ & $\begin{array}{l}137.87(115) \\
\text { Significance } .07\end{array}$ & .028 & .94 & .98 & .98 \\
\hline
\end{tabular}

RMSEA: root mean square error of approximation, GFI: goodness of fit index, NNFI: non-normed fit index, CFI: comparative fit index.

The model fit was measured using the chi-square statistic $(\chi 2)$, root mean square error of approximation (RMSEA), goodness-of-fit index (GFI), non-normed fit index (NNFI), and comparative fit index (CFI). The significant results of the chi-square statistic (see Table 2) imply that the models were adequate (Diamantopoulos \& Siguaw, 2000; Ullman \& Bentler, 2005). The RMSEA results (0.029 and 0.028) are indicative of a very good model fit (Browne \& Cudeck, 1993; Diamantopoulos \& Siguaw, 2000; MacCallum et al., 1996). The GFI result of 0.94 for both models suggests a good fit (Diamantopoulos \& Siguaw, 2000). Also, the NNFI result ( 0.98 for both models) and the CFI results $(0.98$ for both models) indicate a very good fit (Steenkamp \& van Trijp, 1991). Overall, the fit indices shown in Table 2 for the measurement model and the structural model suggest very good fit for both models.

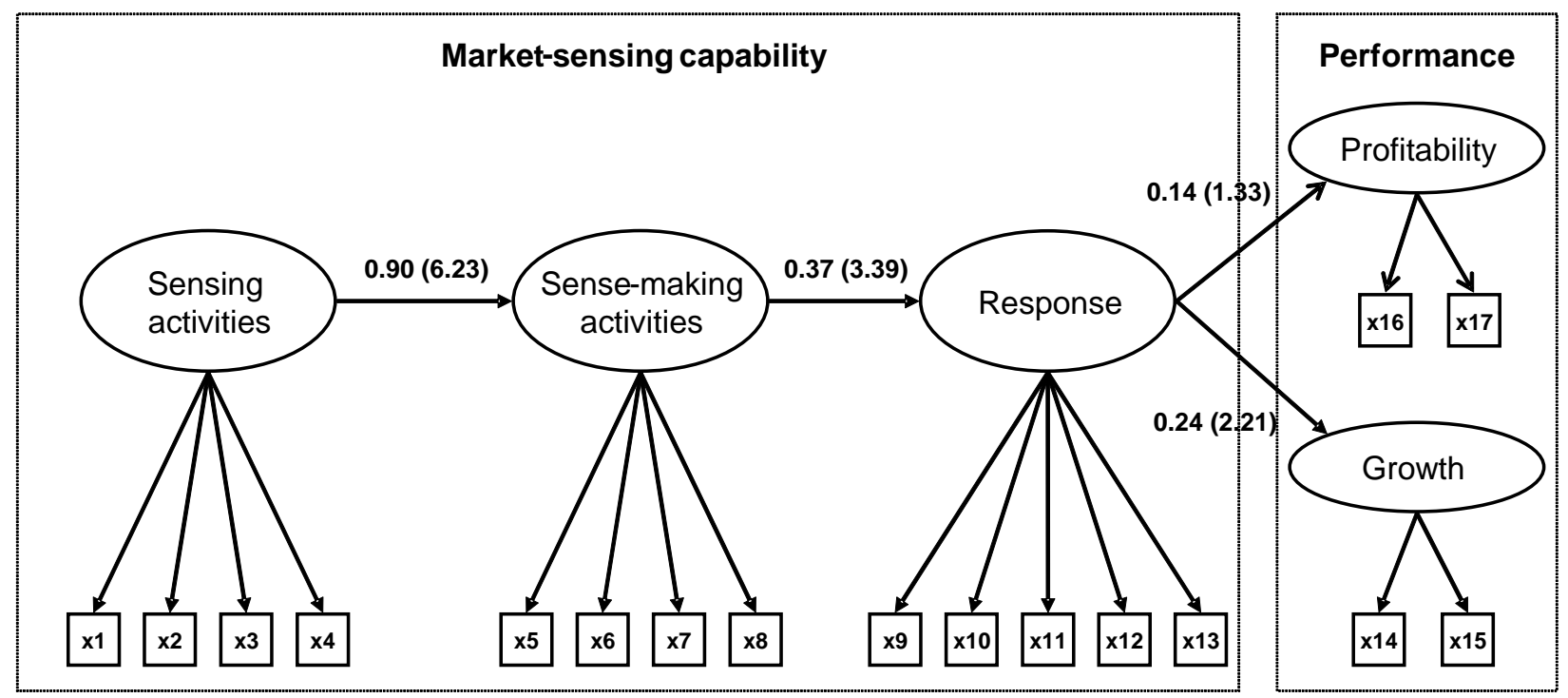

Figure 2 Structural equation model: standardized path estimates

Significance of the path estimates are shown in parentheses (t-value) 
Figure 2 presents the final structural model with standardized path estimates $(\beta)$ and $t$-values. The standardized path estimates $(\beta)$ are used to measure the strength of the relationship between latent variables, and their values range from -1 to +1 . Absolute values close to 1 indicate very strong relationships. The t-values are used to determine whether a particular path estimate $(\beta)$ is significant. If the t-value is greater than 1.96 or less than -1.96 , it indicates that the parameter is statistically significant at the 5 percent significance level (Diamontopoulos \& Siguaw, 2000).

Figure 3 shows that sensing significantly affected sense-making $(\beta=0.90)$. Similarly, there was a positive path from sense-making to response $(\beta=0.37)$. Overall, these results support the view that market-sensing capability consists of the three processes proposed by the present study.

With respect to whether market-sensing capability is related positively to business performance (as measured by growth and profitability), the results show a relatively weak (but statistically significant) positive path $(\beta=0.24)$ from market-sensing capability to growth. This suggests that a high level of market-sensing capability leads to higher growth. However, the path from market-sensing capability to profitability was very weak $(\beta=0.14)$, and was not statistically significant.

The nonexistent effect of market-sensing capability on profitability could be explained by the existence of other factors not considered in the present study. These could be independent variables (having a direct effect on profitability) or moderating variables (affecting the relationship between market-sensing capabilities and profitability). For example, it could be argued that the store location of a given K-retailer, or the existence of local competition, might explain business performance better than any other factor.

\section{CONCLUSION}

The capability-based theory of competitive advantage suggests that firms possessing distinctive capabilities can gain competitive advantages. According to Weerawardena (2003), the capability-based theory differs from other models of competitive strategy in that the former recognizes the crucial role played by entrepreneurial decision-makers in building and sustaining a competitive advantage. Weerawardena (2003) suggests that entrepreneurship, marketing capabilities, and competitive-advantage process are strongly related. 
The present paper has analyzed market-sensing capabilities among a sample of contractually united retail entrepreneurs and assessed the effect of these market-sensing capabilities on their business performance in terms of profitability and growth. Based on the current marketing literature, it was assumed that entrepreneurs that have developed proper sensing, sense-making, and response skills also are able to perform well (see also Atuahene-Gima \& Ko, 2001; Day, 1994; 2002; Weerawardena 2003).

The present study revealed that sensing, sense-making, and response are strongly interrelated. In that sense, Day's (1994; 2002) conceptualization of market-sensing capability is supported by this study. With respect to whether the market-sensing capability of retail entrepreneurs is related positively to their business performance (in terms of growth and profitability), the findings suggest that high level of market-sensing capability does lead to higher growth. However, the study did not find market-sensing capability to have a positive effect on profitability (contra Day, 1994). Since the relation between retail entrepreneurs' market-sensing capability and their profitably was nonexistent, and since the relation between retail entrepreneurs' market sensing capability and their growth was weak, this study could not confirm the quite commonly accepted fact that market- sensing capability is related positively to performance (Day, 1994; 2002; see also Slater \& Narver, 1995).

One possible reason for the relatively weak effect of market-sensing capability on performance may be the difficulty of measuring the abstract construct of market-sensing capability. Especially the response construct should be measured in a more subtle and versatile manner for the reason that at the response stage, the acquired and interpreted knowledge are concretely utilized in the marketing decision-making. Consequently, in addition to items measuring activeness in using different types of knowledge in marketing decision-making, items measuring how innovatively, and in which kind of marketing decision-making areas (e.g., assortment planning, pricing and promotion) the knowledge is used by retail entrepreneurs also should be taken into account in further studies.

The nonexistent (profitability) or weak (growth) effect of market-sensing capability on performance also could be explained by the existence of other factors not considered in the present study. These could be independent variables (having a direct effect on performance) or moderating variables (affecting the relationship between market-sensing capabilities and performance). For example, it could be argued that the store location of a 
given K-retail entrepreneur, or the intensity of local competition, might explain business performance better than any other factor.

Explanation for the nonexistent or relatively weak effect of market-sensing capability on performance also might be found in the governance structures and mechanisms of the K-alliance (e.g., contracts, manuals of practice, and systems of training provided by the central unit). It might be also that governance structures and mechanisms of the contractually integrated retailing organization decrease the autonomy of retail entrepreneurs, which may lead to a situation that they are not able to utilize their market intelligence and knowledge capital when making their marketing decisions. This might lead to a nonexistent or relatively weak effect of market-sensing capability on performance among the contractually united retail entrepreneurs. However, to assess this more directly, it would be necessary to study, in greater detail, the formal and informal governance arrangements in K-alliance and especially actual degree of autonomy allowed to K-retailers in making independent marketing decisions.

With regard to future research avenues, the above mentioned independent and moderating variables should be taken into account in assessing the relationship between retail entrepreneurs' marketing capability and their business performance. In addition to quantitative studies, qualitative studies also could reveal issues that would enable more thorough operationalization of the concepts associated with the market-sensing capabilities of entrepreneurs in a retailing context.

Despite the relatively small number of respondents and the above-discussed limitations of the utilized conceptual model, the basic objectives of the study were met. Most of the results were statistically significant, and the fit indices for the measurement model and the structural model suggested very good fits for both models. The measures also are likely to be valid because they were based on a theoretical background and previous studies on market-sensing capabilities and the related issues. Concentrating on the K-retail entrepreneurs has some implications in terms of the generalizability of the study, i.e., the findings of this empirical analysis are likely to be generalizable at least to the population of K-retail entrepreneurs and, with some caution, also to other contractually united retail entrepreneurs operating in similar kinds of circumstances.

A central managerial implication of this study is that retail entrepreneurs aspiring to develop and preserve their market-sensing capabilities should pay attention to all three basic processes of market-sensing capability, especially their interrelatedness. Contractually united retail entrepreneurs, together with the central unit, should look for 
opportunities to improve the ways in which new knowledge is acquired, analyzed, interpreted, and distributed, as well as utilized in marketing decision-making. According to the present study, it is important for retail entrepreneurs to understand the process nature of market-sensing capability. The study also indicates that mastering marketsensing processes is likely to be crucial for retail entrepreneurs' ability to accomplish sales growth.

\section{REFERENCES}

Atuahene-Gima, K., \& Ko, A. (2001). An empirical investigation of the effect of market orientation and entrepreneurship orientation alignment on product innovation. Organization Science, 12(1), 54-74.

Baker, W. E., \& Sinkula, J. M. (1999). The synergistic effect of market orientation and learning orientation. Journal of the Academy of Marketing Science, 27(4), 411-27

Barney, J. B. (1991) Firm resources and sustained competitive advantage. Journal of Management, 17(1), 99-120.

Bhuiana, S. N., Menguc, B., \& Bell, S. (2005). Just entrepreneurial enough: the moderating effect of entrepreneurship on the relationship between market orientation and performance. Journal of Business Research, 58(1), 9-17.

Browne, M. W., \& Cudeck, R. (1993). Alternative Ways of Assessing Model Fit.. Newbury Park: Sage Publications.

Day, G. S. (1994). The Capabilities of Market-Driven Organizations. Journal of Marketing, 58(4), 37-52.

Day, G. S. (2002). Managing the market learning process. Journal of Business \& Industrial Marketing, 17(4), 240-252.

Day, G. S., \& Wensley, R. (1988). Assessing Advantage: A Framework for Diagnosing Competitive Superiority. Journal of Marketing, 52(2), 1-20.

Diamantopoulos, A., \& Siguaw, J. (2000). Introducing Lisrel: A Guide for the Uninitiated. London: SAGE.

Fahy J., \& Smithee A. (1999). Strategic marketing and the resource-based view of the firm. Academy of Marketing Science Review (Online), 10, from: http://www.amsreview.org/articles/fahy10-1999.pdf

Farrell, M. A., \& Oczkowski, E. (2002). Are market orientation and learning orientation necessary for superior organisational performance? Journal of Market-Focused Management, 5, 197-217. 
Foley, A., \& Fahy, J. (2004). Towards a further understanding of the development of market orientation in the firm: a conceptual framework based on the market-sensing capability. Journal of Strategic Marketing, 12, 219-230.

Hair, J. F., Anderson, R. E., Tatham, R. L., \& Black, W. C. (1998). Multivariate data analysis. New Jersey: Prentice Hall.

Huber, G. (1991). Organizational learning: contributing processes and the literatures. Organizational Science, 2(1), 88-115.

Hult, G. T., \& Ketchen Jr., D. J. (2001). Does market orientation matter? A test of the relationship between positional advantage and performance. Strategic Management Journal, 22(9), 899-906.

Jaworski, B. J., \& Kohli, A. (1993). Market orientation: Antecedents and consequences. Journal of Marketing, 57(3), 53-71.

Jöreskog, Karl, \& Sörbom, D. (2001). LISREL 8: User's Reference Guide. Lincolnwood: SSI (Scientific Software International).

Kaplan, R. S., \& Norton, D. P. (1992). The balanced scorecard - measures that drive performance. Harvard Business Review, 70(1), 71-79.

Kohli, A. K., \& Jaworski, B. J. (1990). Market Orientation: The Construct, Research Propositions, and Managerial Implications. Journal of Marketing, 54(2), 1-18.

Lindblom, A. (2006). Arvoa tuottava kauppiasyrittäjyys ketjuliiketoiminnassa [The Market-sensing capabilities of K-food retailers]. Helsinki: Publications of Helsinki of School of Economics.

MacCallum, R. C., Browne, M. W., \& Sugawara, H. M. (1996). Power Analysis and Determination of Sample Size for Covariance Structure Modelling. Psychological Methods, 1(2), 130-149.

Maltz, E., \& Kohli, A. K. (1996). Market Intelligence Dissemination Across Functional Boundaries. Journal of Marketing Research, 33(1), 47-61.

McKitterick, J. B. (1957). What is the Marketing Management Concept? In: Proceedings of the American Marketing Association Conference, 71-81.

Menon, A., \& Varadarajan, P. R. (1992). A Model of Marketing Knowledge Use Within Firms. Journal of Marketing, 56(4), 53-71.

Mitronen, L. (2002). Hybridiorganisaation johtaminen. [Management of Hybrid Organization]. Tampere: Doctoral dissertation, University of Tampere.

Mitronen, L. \& Möller, K. (2003). Management of hybrid organisations: a case study in retailing. Industrial Marketing Management, 32(5), 419-429. 
Moorman, C., Zaltman, G., \& Deshpande, R. (1992). Relationships Between Providers and Users of Market Research: The Dynamic of Trust Within and Between Organizations. Journal of Marketing Research, 29, 314-328.

Morgan, R. E., \& Strong, C. (2003). Business performance and dimensions of strategic orientation. Journal of Business Research, 56(3), 163-176.

Narver, J. C., \& Slater, F. S. (1990). The Effect of Market Orientation on Business Profitability. Journal of Marketing, 54(4), 20-36.

Noble, C. H., Sinha, R. K., \& Kumar, A. (2002). Market Orientation and Alternative Strategic Orientations: A Longitudinal Assessment of Performance Implications. Journal of Marketing, 66(4), 25-40.

Nunnally, J. C. (1978). Psychometric Theory. New York: McGraw-Hill.

Nunnally, J. C., and Bernstein, I. H. (1994). Psychometric Theory. New York: McGrawHill.

Prahalad, C. K., \& Hamel, G. (1990). The Core Competence of the Corporation. Harvard Business Review, 68(3), 79-91.

Rumelt, R. P. (1984). Competitive Strategic Management: Towards a strategic theory of the firm. Englewood Cliffs NJ: Prentice-Hall,.

Santos-Vijande, M., Sanzo-Pérez, M. J., Álvarez-González, L., and Vázquez-Casielles, R. (2005). Organizational learning and market orientation: interface and effects on performance. Industrial Marketing Management, 34(3), 187-202.

Srivastava, R. J., Fahey, L., \& Christensen, H. K. (2001). The resource-based view and marketing: The role of market-based assets in gaining competitive advantage. Journal of Management, 27(6), 777-802.

Slater, F. S. \& Narver, J. C. (1995). Market orientation and the learning organization. Journal of Marketing, 59(3), 63-75.

Slater, F. S. \& Narver, J. C. (2000a). Intelligence generation and superior customer value. Journal of the Academy of Marketing Science, 28(1), 120-128.

Slater, F. S. \& Narver, J. C. (2000b). The Positive Effect of a Market Orientation on Business Profitability: A Balanced Replication. Journal of Business Research, 48(1), 69-73.

Srivastava, R. K., Shervani, T. A., \& Fahey, L. (1998). Market-based assets and shareholder value: a framework for analysis. Journal of Marketing, 62(1), 2-18. 
Steenkamp, J. B. E. M., \& van Trijp, H. C. M. (1991). The use of LISREL in Validating Marketing Constructs. International Journal of Research in Marketing, 8(4), 283299.

Teece, D. J., Pisano, G., \& Shuen, A. (1997). Dynamic capabilities and strategic management. Strategic Management Journal, 18(7), 509-533

Vorhies, D. W. (1998). An investigation of the factors leading to the development of marketing capabilities and organizational effectiveness. Journal of Strategic Marketing, 6(1), 3-24.

Vorhies, D. W., \& Harker, M. (2000). The Capabilities and Performance Advantages of Market-Driven Firms: An Empirical Investigation. Australian Journal of Management, 25(2), 145-162.

Vorhies, D. W., \& Morgan, N. A. (2005). Benchmarking Marketing Capabilities for Sustainable Competitive Advantage. Journal of Marketing, 69(1), 80-94.

Weerawardena, J. (2003). Exploring the role of market learning capability in competitive strategy. European Journal of Marketing, 37(3/4), 407-429.

Weerawardena, J., \& O'Cass, A. (2004). Exploring the characteristics of the marketdriven firms and antecedents to sustained competitive advantage. Industrial Marketing Management, 33(5), 419- 428.

Wernerfelt, B (1984). A resource-based view of the firm. Strategic Management Journal, $5(2), 171-180$. 